\title{
Towards cost-effective indicators to maintain Natura 2000 sites in favourable conservation status. Preliminary results from Cansiglio and New Forest
}

\begin{abstract}
Cantarello $\mathrm{E}^{*(1)}$, Newton $\mathrm{A}^{(2)}$
Natura 2000 is a coherent ecological network of special areas, designated under the Habitat and Birds EEC Directives, to assist in the maintenance of biodiversity in the European territory. It is now widely recognised that one of the most effective ways to maintain biodiversity is to preserve habitats in a favourable conservation status as required of Member States by the Habitat Directive. As a consequence, approaches are needed to define when habitats are of favourable conservation status and to assess the maintenance or the restoration of this condition. This could be partly achieved through the selection of appropriate indicators of favourable conservation status. Once such indicators have been identified and tested, they could be used for monitoring the impact of managing Natura 2000 sites, and could assist in achieving policy goals. Although many indicators have been proposed, particularly for forested habitats, few have been adequately field tested. Little research has been undertaken to identify indicators that are cost-effective, a key characteristic given that resources for habitat assessment and monitoring are often limited. Therefore, this research aims both to identify appropriate indicators to maintain favourable conservation status, and to evaluate their relative cost-effectiveness for two selected Natura 2000 sites: the Cansiglio Forest (North Italy) and the New Forest (South England). The following will highlight the results of the preliminary research.
\end{abstract}

Keywords: indicators, biodiversity, Natura 2000, forest habitats

\section{Introduction}

The Natura 2000 network and favourable conservation status

Natura 2000 is a coherent ecological network of special areas selected to assist in the maintenance of biodiversity in the European territory. It is composed of two different kinds of sites: firstly, the special areas of conservation (SAC) designated under the Habitats Directive (Council Directive 92/43/EEC) on the conservation of natural habitats and of wild fauna and flora, and secondly the special protection areas (SPA)

(1)Dipartimento Territorio e Sistemi AgroForestali, Università di Padova, viale dell'Università 16, 35020 Legnaro (PD);

${ }^{(2)}$ School of Conservation Sciences, Bournemouth University, Talbot Campus Fern Barrow, Poole Dorset, BH12 5BB (UK)

*Corresponding Author: Elena Cantarello (elena.cantarello@unipd.it).

Citation: Cantarello E, Newton A, 2008. Towards cost-effective indicators to maintain Natura 2000 sites in favourable conservation status. Preliminary results from Cansiglio and New Forest. iForest 1: 75-80

[online: Feb 28, 2008] URL:

http://www.sisef.it/iforest/ designated under the Birds Directive (Council Directive 79/409/EEC) for the conservation of wild birds. These two EEC directives define an integrated framework to identify, to maintain and to protect natural sites as a whole; they represent the European Union's most concrete act towards the achievement of international biodiversity policy commitments, such as the Bern Convention 82/72/EEC and the Biodiversity Convention 93/626/EEC (Barbati et al. 2002).

According to the Habitats Directive, Natura 2000 "shall enable the natural habitat types and the species habitats listed in Annex I and Annex II to be maintained or, where appropriate, restored to a favourable conservation status in their natural range" (Article 3). The conservation status will be taken as "favourable" when:

- the natural range and areas the natural habitat types cover are stable or increasing;

- the specific structure and functions which are necessary for the natural habitat types long-term maintenance exist and are likely to continue to exist for the foreseeable future;

- the population dynamics data on the species concerned indicate that they are maintaining themselves on a long term basis as viable components of their natural habitats; - the natural ranges of the species are neither being reduced nor are likely to be reduced for the foreseeable future;

- there is, and will probably continue to be, a sufficiently large habitat to maintain its population on a long term basis (Article 1). To achieve the aim of the Habitat Directive, i.e., to contribute towards ensuring biodiversity, it is reported the Member State shall:

- establish the necessary conservation measures involving appropriate management plans specifically designed for the sites or integrated into other development plans, and appropriate statutory, administrative or contractual measures which correspond to the ecological requirements of the natural habitat types and the species present on the sites;

- take appropriate steps to avoid, in the special areas of conservation, the deterioration of natural habitats as well as disturbance of the species for which the areas have been designated (Article 6).

Therefore, when management of a Natura 2000 site is required, it is fundamental to identify, evaluate and monitor the site over time, to ensure that natural habitat and species are being maintained in a favourable conservation status.

\section{Indicators and cost-effectiveness}

Criteria and indicators are widely used to evaluate and monitor conservation status, particularly for forested habitats at the landscape scale (e.g., Noss 1990, OECD 1994, CIFOR 1999, Noss 1999, Larsson 2001, EEA 2003, FAO 2003, MCPFE 2003).

A number of different definitions of indicators have been proposed:

- a complex situation's synthesis, i.e., one or a group of characteristics that allowed us to understand a specific phenomenon (Schmidt di Friedberg 1987);

- measurable surrogates for environmental end points (Noss 1990);

- qualitative or quantitative statistic variables, representative of an environmental factor and related to a specific subject (Colombo \& Malcevschi 1996);

- a parameter or a related parameter value that gives information about a phenomenon and for which meaning goes beyond the specific characteristics associated with the parameter value (OECD 1994);

- a complex or simple entity whose function is to indicate the state or the change of phenomena that are impossible to directly measure (ANPA 2000).

As it is expressed by Noss (1990), Shaw \& Wind (1997), Ferris \& Humphrey (1999), ANPA (2000) and Kapos et al. (2001), to be applicable and effective an indicator should 
have the following properties:

- scientific and theoretical value;

- sensitive to a wide range of stresses to provide an early warning of change;

- distributed over a broad geographical area or otherwise widely applicable;

- require easily collected and cost-effective data to implement them;

- relevant to ecologically significant phenomenon;

- easy to understand even by non-specialists (i.e., managers, politicians).

As a single indicator with all these desirable properties has not yet been identified, a core set or suite of indicators is normally required.

Given all the above definitions of indicators and the requirements to confidently apply them, their relevance to managing and monitoring Natura 2000 sites should immediately be apparent, yet this issue has received relatively little previous attention from past researchers (i.e., CCW 2000, Ministero Ambiente 2003, JNCC 2004).

Little research has been undertaken to identify indicators that are cost-effective, a key characteristic given that resources for habitat assessment and monitoring are often limited (Wätzold \& Schwerdtner 2005). Also, not much work has been carried out on applying indicators at the local scale, where management decisions are typically made. Thus, this research aims to identify both appropriate indicators for two selected Natura 2000 sites The Cansiglio Forest (Northern Italy) and The New Forest (Southern England), and to evaluate their relative cost-effectiveness.

\section{Study areas}

\section{The Cansiglio Forest}

\section{General description}

The Natura 2000 site Cansiglio Forest covers $50.6 \mathrm{~km}^{2}$ in the North Italy Alpine biogeographic region (latitude 46 $04^{\prime} 45^{\prime \prime}$ north, longitude $12^{\circ} 24^{\prime} 42^{\prime \prime}$ east). From 2001 it has been included on the Site of European Community Interest list according to the Habitat Directive and from 2003 it has been classified as a Special Protection Area according to the Bird Directive. IT3230077 is the Natura 2000 identification site code.

According to the European Community Commission's III level classification applied in the CORINE Land Cover project, $34.4 \%$ of the Cansiglio Forest's area is represented by broadleaved woodland, $19.4 \%$ is covered by plantation, $29.6 \%$ is mixed woodland, 14 $\%$ is grassland and the remaining $2.6 \%$ is represented by new forest stands. According to the "Interpretation Manual of European Union Habitats" (European Commission/DG Environment 2003a) the majority of the woodland is represented by 9130 Asperulo-
Fagetum beech forest and 9140 Acidophilous Picea forests of the montane to alpine levels (Vaccinio-Piceetea). Asperulo-Fagetum beech forest comprises the two standlevel typology (sensu Del Favero 1992) "Faggeta montana tipica" and "Abieteto esomesalpico montano"; Acidophilous Picea forests comprise the stand-level typology "Pecceta secondaria montana".

The Forest has been managed from a very long time in the past. The Serenissima Republic of Venice in 1548 designated Cansiglio as a restricted area subject to special forest laws to provide timber for its powerful ship arsenal. Beeches were especially used for oars, but they were also important as a building material and for charcoal making (Caniato 2001). The French and Austrian Governments forest management initiative turned to timber production carrying out a large Venetian project aiming to replace beeches with conifers (Lazzarini 1997). Forests had been managed without particular objectives until the beginning of the Italian Kingdom in 1871, when it was declared an inalienable state domain. Today forest management is inspired by naturalistic criteria where the first aim is to achieve an ecological stable forest. Tree cutting aims to ensure natural regeneration, to maintain and improve biodiversity and finally to prevent epidemics; some areas are also left to natural evolution. In 2005 Cansiglio was certified according to the PEFC forest sustainable management scheme.

\section{Sampling units investigated}

As the Cansiglio forest covers 5060 hectares it was not possible to survey the whole area with the available human resources so monitoring methods were applied to a sample area. Some 30 units were surveyed. As mentioned above, this research focuses particularly on the local scale. Therefore, sampling units were defined according to forest management units as reported in Del Favero (2000) managed as high forest and to the regional natural reserves "Pian di Landro Baldassarre" and "Piaie Longhe - Millifret" units, as reported in Lasen (2000).

A preliminary selection was made deleting those units that were less than one hectare (ha) in size. The resulting 187 sampling assessment units are shown in Fig. 1. A second selection was made by randomly choosing 30 units from the above 187 using ArcGIS $8.3^{\circ}$ Hawth's Analysis Tools ${ }^{\circ} 2002$ Version 2.00 extension. The 30 selected sampling units covered 787 ha, equal to $15.6 \%$ of the Natura 2000 site and representing $21.2 \%$ of the total forested sampling units.

\section{The New Forest}

\section{General description}

The New Forest Natura 2000 site covers
$292.9 \mathrm{~km}^{2}$ and is located in the South England Atlantic biogeographic region (latitude $50^{\circ} 51^{\prime} 59^{\prime \prime}$ north, longitude $01^{\circ} 40^{\prime} 50^{\prime \prime}$ west). From 2004 it has been confirmed as a Site of European Community Interest according to the Habitat directive and from 2005 it has been designated as SCA. UK0012557 is the Natura 2000 identification site code (JNCC 2006).

The New Forest is mainly covered by woodland. More precisely $46 \%$ of the entire surface is represented by broadleaved, mixed and yew woodland, $34 \%$ by heath and scrub, $7 \%$ by grassland and $3 \%$ by bogs. As it is reported in the Natura 2000 data form, the majority of the woodland is represented by 9120 Atlantic acidophilous beech forest with Ilex and sometimes also Taxus in the shrub layer (Quercion robori petraeae or Ilici-Fagenion) and by 9130 Asperulo-Fagetum beech forest. Ilici-Fagenion occurs on acid soils and falls within two National Vegetation Classification types: W14 Fagus sylvatica - Rubus fruticosus woodland and W15 Fagus sylvatica - Deschampsia flexuosa woodland; Asperulo-Fagetum beech forest occurs on circumneutral to calcareous soils and it mostly corresponds to W12 Fagus sylvatica - Mercurialis perennis woodland and W14 Fagus sylvatica - Rubus fruticosus woodland (English Nature 2001).

The New Forest was set aside by William the Conqueror in 1079 to give sanctuary to deer and other animals, which were hunted by Royal parties. Trees were protected by Forest law as they provided food and shelter for the deer. As time passed, interest in the forests deer declined and the New Forest started to be managed for timber cultivation. Most coppices were established by enclosing existing woodlands to produce shoots suitable for fodder, firewood, and hurdle fences or for converting into charcoal. Later with increasing pressures to supply the growing Royal Navy, new areas were enclosed and planted with conifers to produce timber for shipbuilding. The first and second World Wars resulted in a very chaotic scene. Vast areas of broadleaves were planted with fastgrowing conifers for the war effort, some others, were taken over by the military (Tubbs 1986).

In 1945 the ownership changed hands from the Crown to the Minister of Agriculture and nature conservation started to play a more important role in the forest, exercising an even greater influence over its management. However, the Forestry Commission, which took over management from the Crown, continued to convert some inclosures from broadleaves to conifers and pressures from tourism began to rapidly increase. Today the New Forest is regarded as a site of national heritage and importance due to the conservation of its traditional character with the ancient and ornamental woodland being con- 


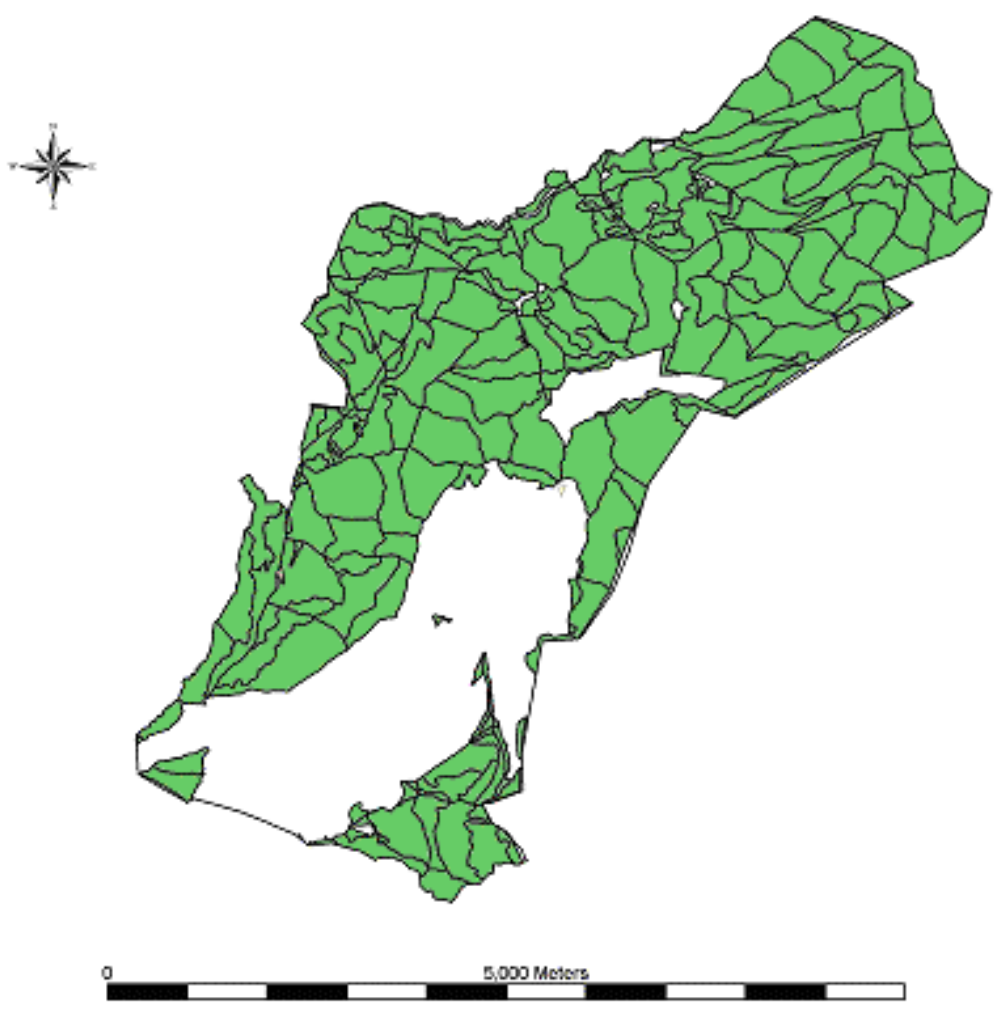

Fig. 1 - Assessment units in The Cansiglio Forest. Data provided by Del Favero (2000) - reproduced with permission. ods. The first method was based on a survey plot commonly used by forest ecologists, in which a full list of indicators was taken into consideration. The second was based on a point transect method, less commonly used by ecologists than the plot-based approach, but considered more time-efficient by some (e.g., Hall 1991, Sheil et al. 2003). In this case, data were collected for a shorter list of indicators. A more detailed description about the two methods is provided below.

\section{Plot method}

For each of the 30 selected units, a 50 by $50 \mathrm{~m}$ plot was created at a randomly selected location within the unit. The start point coincided with the south-west corner of the plot, and was located in the field using GPS, given the coordinates randomly generated by using ArcGIS 8.3 $3^{\circ}$ Hawth's Analysis Tools ${ }^{\circ}$ 2002 Version 2.00 extension.

The basis for selecting indicators to look for in each plot was provided by:

- the existing interpretation of the total body of EU law (i.e., European Commission/DG Environment 2000, European Commission/DG Environment 2003b);

- initiatives to promote sustainable forest management and other processes such as the "Ministerial Conference for the Protection of forest in Europe" (MCPE), the "Indicators for monitoring and evaluation of forest biodiversity in Europe" project served (Goriup 1999). In 2005 it was recognised as a National Park.

\section{Sampling units investigated}

As it was not possible to survey the whole area with the available human resources, monitoring methods were applied to a sample area of 30 units. When considering the sample units to investigate it was decided to use the Sites of Special Scientific Interest broadleaved, mixed and yew woodland units reported by the English Nature website (http:/www.english-nature.org.uk), which are used in current monitoring of the conservation status of the site.

A preliminary selection was made deleting those units less than one hectare in size. The resulting 142 sampling assessment units are shown in Fig. 2. A second selection was made by randomly choosing 30 units from these 142 using the ArcGIS 8.3 ${ }^{\circ}$ Hawth's Analysis Tools $^{\mathcal{O}} 2002$ Version 2.00 extension. The 30 sampling units covered 2702 ha, equal to $9.2 \%$ of the Natura 2000 site and representing $22.4 \%$ of the total forested sampling units.

\section{Materials and methods}

For the purpose of this research, i.e., to identify appropriate indicators at the local scale and to evaluate their cost-effectiveness, it was decided to apply two sampling meth-

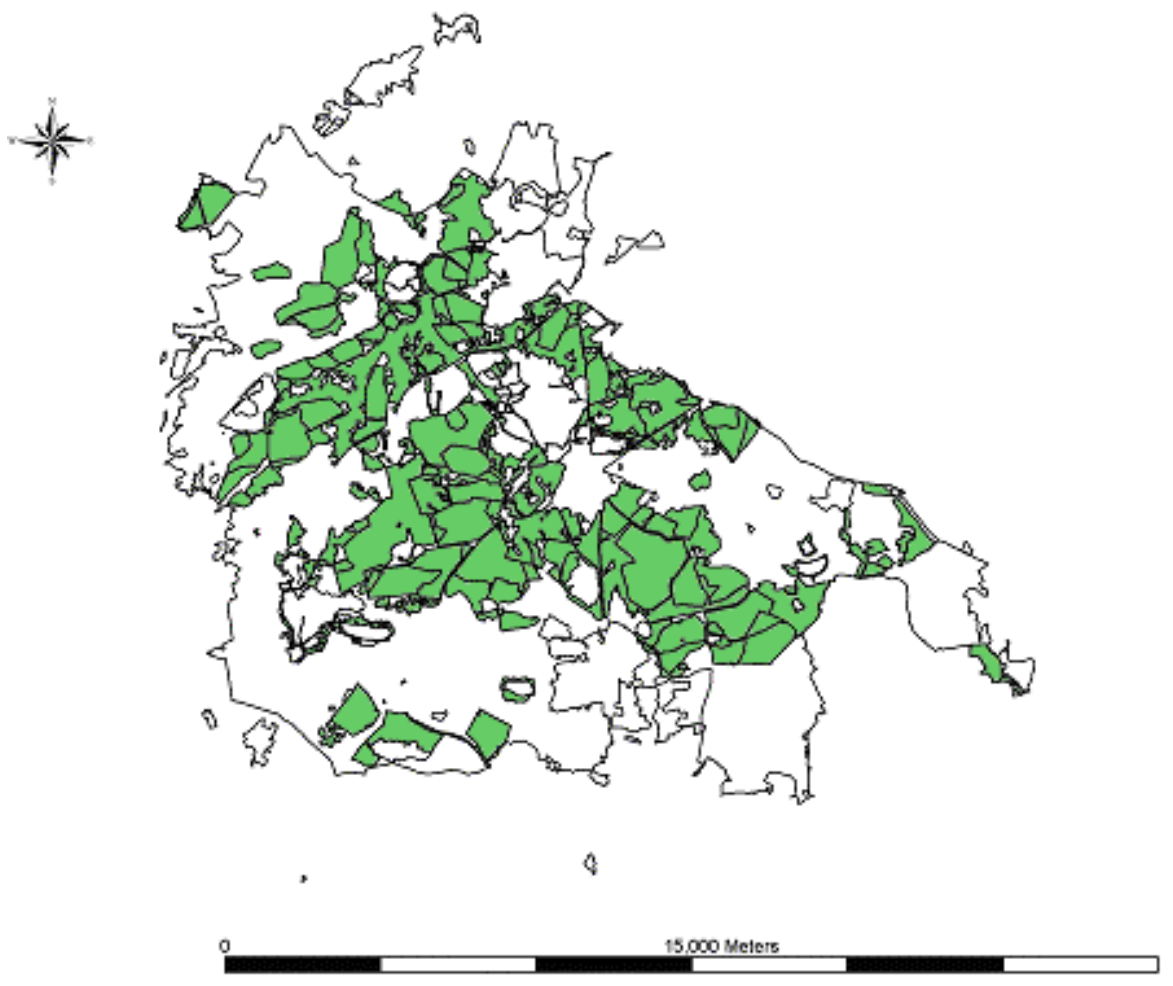

Fig. 2 - Assessment units in the New Forest. Data provided by English Nature (C) 1998-2005 English Nature - reproduced with permission. 
(BEAR) and the Italian "Monitoring of Forest Ecosystems" program (CONECOFOR) and "Carta della Natura" project (APAT 2004);

- the proposed National Programme for monitoring Natura 2000 sites (Ministero dell'Ambiente e della Tutela del Territorio 2003, JNCC 2004);

- relevant scientific literature (i.e., Hall 1991, Noss 1990, Keddy \& Drummond 1996, Prabhu et al. 1996, Shaw \& Wind 1997, Ferris \& Humphrey 1999, Gasparini \& Tosi 2000, Lindenmayer et al. 2000, Christensen et al. 2005, Lamonaca 2005).

Indicators were selected that were relatively easy to measure, not requiring too much expert knowledge and interpretation.

Data for survey were collected to calculate the 22 indicators listed below:

- number and species of stems (stems ha' ${ }^{-1}$ ), basal area $\left(\mathrm{m}^{2} \mathrm{ha}^{-1}\right)$, mean diameter and standard deviation of diameters $(\mathrm{cm})$, number of big trees (diameter at breast height bigger than $50 \mathrm{~cm}$ );

- dominant and mean height (m);

- number and species of saplings (number of individuals lower than $10 \mathrm{~cm}$ in diameter ha $^{-1}$ );

- crown coverage $(\%)$;

- vertical and horizontal structure (qualitative groups);

-volume and degree of decomposition both of fallen and standing dead wood more than $10 \mathrm{~cm}$ in diameter $\left(\mathrm{m}^{3} \mathrm{ha}^{-1}\right)$;

- ground flora vegetation (number of species and percentage); a species identification and an estimate of their coverage were performed using Braun-Blanchet indices. A 20 by $20 \mathrm{~m}$ subplot in the Cansiglio Forest and a 10 by $10 \mathrm{~m}$ subplot in the New Forest were used for this indicator; the area of the subplot was determined from a species/area curve (e.g., Roberts-Pichette \& Gillespie 1999);

- number and species of seedlings (number of individuals lower than $1.3 \mathrm{~m}$ in height). A 3.5 by $3.5 \mathrm{~m}$ subplot in Cansiglio Fores and a 10 by $10 \mathrm{~m}$ subplot in New Forest were used; subplot measures were derived from a number of individuals/area curve;

- damage caused by wind, snow, forestry, deer, insects, fungi, fire were recorded only when affecting more than $10 \%$ of the plot area.

The time required to collect data for the above indicators was recorded. The survey teams were usually composed of two people.

\section{Transect method}

For each of the 30 selected units a northorientated $100 \mathrm{~m}$ transect was also created (Fig. 3). The start-point was coincident with the south-west corner of the plot. When the transect was found to end in a different unit, an east-west transect was used instead.

Data were collected using a distance-based

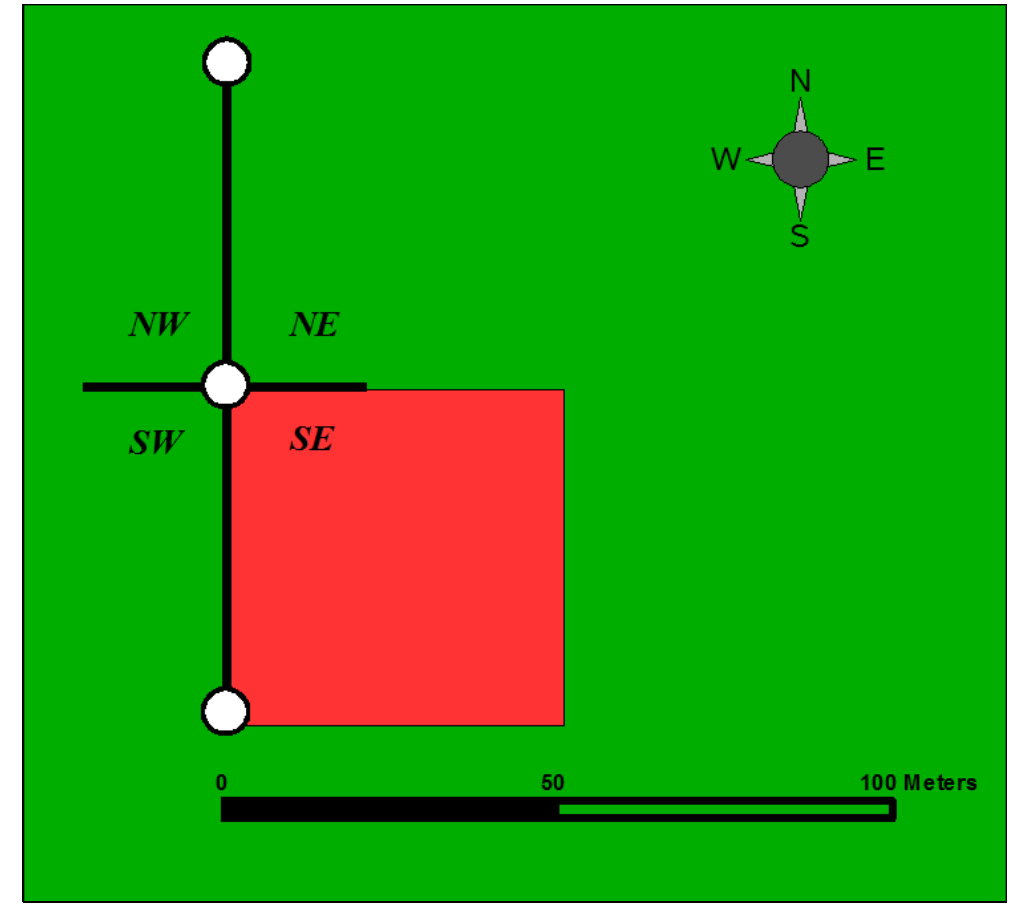

Fig. 3 - Illustration of the $100 \mathrm{~m}$ transect which the sampling transect method is based upon.

sampling method, combining the point centre quarter method (e.g., Morisita 1954) with the multiple-nearest-tree technique (e.g., Hall 1991). For each transect, three fixed points were surveyed $50 \mathrm{~m}$ distant from each other. At each point, distance and diameter of the first 4 trees per quarter were collected; therefore a total number of 48 trees were sampled for each transect.

With the transect-based method, only number of stems, species number and diameter at the breast height (dbh) were taken into consideration as indicators. As in the plot method, time to collect the data was recorded. The survey teams were usually composed of two people.

\section{Results}

In order to answer the research questions the following statistical analyses were performed:

- three paired- $t$ tests to compare the time necessary to collect data in the plot method with the time required to collect data using the transect method;

- a forth paired- $t$ test to evaluate differences in number of stems and basal area using the two methods;

- a correlation analysis between indicators considered in the plot method to examine relationships which could allow values from one indicator to be predicted from another, and thereby reducing the amount of field data to be collected.

\section{Cost effectiveness}

To assess cost-effectiveness three paired-t tests were performed comparing: (i) time spent setting the plot and the transect up, (ii) time collecting data for the indicators in common between the two methods, i.e., number of trees and basal area, (iii) time requiring for the indicators considered in the plot and the indicators considered in the transect method.

In the Cansiglio Forest it was found that:

- the time spent to set-up the plot is longer than the time spent to set-up the transect; respectively $45 \pm 1.8 \mathrm{mins}$ and $24 \pm 1.4$ mins $(P<0.001)$;

- the same time is required to measure dbh in the two methods; $41 \pm 3.3$ mins in the plot, $47 \pm 3.0 \mathrm{mins}$ in the transect $(P>0.05)$;

- the time spent for the 22 diversity indicators considered in the plot is longer than the time spent for the indicators i.e., number and species of trees and basal area in the transect; respectively $150 \pm 7.0$ mins; $47 \pm$ 3.0 mins $(P<0.001)$.

Therefore, when considering the two methods in their entirety, the plot method requires more time $(195 \pm 7.6 \mathrm{mins})$ than the transect method ( $71 \pm 3.8$ mins, $P<0.001)$.

In the New Forest it was similarly found that:

- the time spent to set-up the plot is longer than the time spent to set-up the transect; respectively $37 \pm 2.6 \mathrm{mins}$ and $18 \pm 1.0$ mins $(P<0.001)$;

- the same time is required to measure $\mathrm{dbh}$ in the two methods; $59 \pm 3.8$ mins in the plot, $54 \pm 2.7$ mins in the transect $(P>0.05)$;

- the time spent to collect the data for all diversity indicators in the plot is longer than 
the time spent to collect indicators in the transect; respectively $108 \pm 4.5 \mathrm{mins}$ and $54 \pm 2.7$ mins $(P<0.001)$.

Therefore, when considering the two methods in their entirety, the plot-based method requires more time (144 $\pm 6.2 \mathrm{mins})$ than the transect $(71 \pm 3.3$ mins, $P<0.001)$.

\section{Data accuracy and consistency}

Given that in both study areas the two methods differed in the time required for the data to be collected, a paired- $t$ test was performed to see if the estimates of biometric indicators, i.e., the number of trees per ha and the basal area per ha, were the same using the plot-based and transect-based methods.

In the Cansiglio Forest it was found that:

- the same number of trees per ha was recorded using both methods; $342 \pm 33$ trees hain the plot; $313 \pm 33$ trees ha ${ }^{-1}$ in the transect $(P>0.05)$;

- the plot method gives us the same value of basal area per ha than the transect one; 35.2 $\pm 1.73 \mathrm{~m}^{2} \mathrm{ha}^{-1}$ in the plot; $33.6 \pm 2.33 \mathrm{~m}^{2}$ $\mathrm{ha}^{-1}$ in the transect $(P>0.05)$;

In the New Forest it was similarly found that:

- the same number of trees per ha in both methods; $256 \pm 19$ trees ha $^{-1}$ in the plot; $237 \pm 26$ trees $\mathrm{ha}^{-1}$ in the transect $(P>0.05)$;

- the plot method gives the same value of basal area per ha than the transect; $33.7 \pm$ $1.93 \mathrm{~m}^{2} \mathrm{ha}^{-1}$ in the plot; $31.5 \pm 2.56 \mathrm{~m}^{2} \mathrm{ha}^{-1}$ in the transect $(P>0.05)$.

\section{Correlation between indicators}

A correlation analysis was performed between indicators considered in the survey plot in order to test the possibility of prioritizing some of them.

In the Cansiglio Forest some statistically significant relationships were found between:

- the volume of fallen dead wood and the stems number and the basal area (respectively Pearson's $\mathrm{r}=0.524, P<0.001$; Pearson's $r=0.416, P<0.05$ );

- the decomposition of fallen dead wood and the basal area (Pearson's $\mathrm{r}=-0.368$, $P<0.05$ );

- the volume of standing dead wood and the stem number and basal area and the volume of fallen dead wood (respectively Spearman's $r=0.419, P<0.05$; Spearman's $\mathrm{r}=0.381, P<0.05$; Spearman's $\mathrm{r}=0.388$, $P<0.05$ );

In the New Forest some statistically significant relationships were found between:

- the volume of standing dead wood and basal area and the number of big trees (Spearman's $\mathrm{r}=0.533, P<0.001$; Spearman's $\mathrm{r}=$ $0.456, P<0.05$ );

- the degree of decomposition of standing dead wood and the basal area (Pearson's $\mathrm{r}$ $=0.445, P<0.05$ ).

\section{Discussion}

The overall aim of this study was to define a cost-effective methodological framework based on indicators for biodiversity to monitoring and reporting on the conservation status of woodland units protected within Natura 2000 sites. Two monitoring methods were applied: (i) the plot based method in which data were collected for a core set of 22 indicators and (ii) the transect based method in which only 3 indicators were taken into consideration. Indicators focused on forest structure and stems composition in both methods, on saplings, herbal layer composition and dead wood only in the plot method.

Regarding the cost-effectiveness aspect of the two monitoring methods the study confirmed that in both study areas the plot-based method is less efficient in terms of time taken to collect the data (195 mins in the Cansiglio, 144 mins in the New Forest) than the transect method (71 mins in both areas $P<0.001)$. However when only number of stems and basal area are considered as indicators within the two methods, then there is no significant difference between the time taken (41 mins in the plot, 47 mins in the transect in the Cansiglio, 59 mins in the plot, 54 mins in the transect in the New Forest $(P>0.05)$. But the time to set up the plot was found to be longer than the time to set up the transect. Therefore when including the setting up, the plot method appeared to be more time consuming than the transect based even in the case of considering the only indicators in common.

Regarding the accuracy and consistency of data collected no difference in the number of stems (342 stems ha ${ }^{-1}$ in the Cansiglio, 256 stems $\mathrm{ha}^{-1}$ in the New Forest referring to the plot; 313 stems ha $^{-1}$ in the Cansiglio, 237 stems ha $^{-1}$ in the New Forest referring to the transect) and basal area $\left(35.2 \mathrm{~m}^{2} \mathrm{ha}^{-1}\right.$ in the Cansiglio, $33.7 \mathrm{~m}^{2} \mathrm{ha}^{-1}$ in the New Forest referring to the plot; $33.6 \mathrm{~m}^{2} \mathrm{ha}^{-1}$ in the Cansiglio, $31.5 \mathrm{~m}^{2} \mathrm{ha}^{-1}$ in the New Forest referring to the transect) were found using the two monitoring methods.

Considering both study areas, the correlation analysis found many significant relationships between indicators especially for those related to basal area and dead wood. In particular the volume of standing dead wood was positively correlated with basal area in both sites. However, more research needs to be done in order to prioritize cost effective indicators and reducing in this way field efforts.

Natura 2000 calls for a level of environmental protection and it requires environmental considerations to be integrated into other policies with a view to promoting sustainable development. This is especially important for forest ecosystems, as forest habitats and forest species will be included in the
Natura 2000 network in over half of all sites. This means that more attention will have to be paid to integrating conservation objectives into forest management. A prerequisite to achieve this is effective and relevant monitoring through cost-effective indicators covering the different elements of biodiversity at the scale of forest management units. The DG Environment B2 (Nature and Biodiversity) stressed that: i) monitoring of habitats and species is an obligation under Article 11 of the Habitats Directive; ii) data eventually reported to the Commission needs to be comparable and compatible in order to allow for analysis at a European Union scale (European Commission 2005). However, yet issues relating to the cost-effectiveness of biodiversity monitoring have not figured in European conservation research and policy making (BEF 2005).

This work has been a contribution to the challenging task of monitoring implementation in Natura 2000 policy context. Two biodiversity monitoring methods within two Natura 2000 sites have been compared. Results suggested that surveying a subset of indicators using transect methods may provide the most efficient way for environmental agencies, and any organisations dealing with the management of Natura 2000 forested sites of assessing the conservation status of forested habitats at a local scale. The proposed analysis does not pretend to be exhaustive and the need for further research is acknowledged.

Natura 2000 biodiversity monitoring issues could be greatly reduced in the future by:

- the use of another monitoring scheme to find out if there are simpler ways of achieving the same conditions assessment, such as structured walks covering a larger area, in which a simple questionnaire is completed. A questionnaire based method should assist forest managers in evaluating conservation status in a less time-consuming way than the plot and the transect method; it should also involve less physical work and fewer specialist ecological skills. Application of this method is described by English Nature (2003) in lowland heathland and a similar approach is already used by the English Nature to assess the New Forest (personal communication: Craig A. June $8^{\text {th }} 2004$, Westerhoff D. May $25^{\text {th }}$ 2005);

- a study to find out to what extent the practice of scoring indicators (e.g., Lähde et al. 1999, Du Bus De Warnaffe \& Devillez 2002, APAT 2004) is a useful approach for assessing conservation condition.

\section{Acknowledgements}

The work has been funded by Veneto Agricoltura (Veneto Region Agency for the Agricultural, Forestry and Agro-food sectors) and by the Italian Ing. Aldo Gini foundation. The 
Authors thanks Padua University and Bournemouth University for the use of their facilities and support.

\section{References}

ANPA (2000). Selezione di indicatori ambientali per i temi relativi alla biosfera. RTI CTN CON $1 / 2000$.

APAT (2004). Carta della Natura alla scala 1:50.000: metodologie di realizzazione. Manuali e Linee Guida 30/2004, Roma.

Barbati A, Corona P, Grafi G, Marchetti M, Maggiore AM, Roncheri I (2002). La gestione forestale nei SIC/ZPS della rete Natura 2000: chiavi di interpretazione e orientamenti per l'applicazione della direttiva Habitat. Monti e Boschi 2: 4-13.

BEF (2005). Workshop on implementation of biodiversity monitoring requirements according requirements to the Habitats Directive in the EU Member States. 3-4 March, Sigulda, Latvia.

Caniato G (2001). La foresta del Cansiglio sotto il dominio della Serenissima Repubblica. [online] URL: http:/www.cansiglio.it/biblioteca/seminario/serenissima.pdf

CCW (2000). Integrating monitoring with Management Planning: a demonstration of good practice on Natura 2000 sites in Wales. Final Report December 2000. In: Integrating monitoring with management plannning: a demonstration of good practice on Natura 2000 sites in Wales (CCW ed). Life-Nature Project No LIFE95 NAT/UK 000821 (available on CD-rom), CCW, Bangor.

Christensen M, Hahn K, Mountford EP, Odor P, Standovar T, Rozenbergar D, Diaci J, Wijdeven S, Meyer P, Winter S, Vrska T (2005). Dead wood in European beech (Fagus sylvatica) forest reserves. Forest Ecology and Management 210 (1-3): 267-282.

CIFOR (1999). C\&I toolbox series. CIFOR, Jakarta, 23 May 2005.

Colombo AG, Malcevschi S (1996). Manuale AAA degli indicatori per la valutazione di impatto ambientale. Associazione Analisti Ambientali, Milano.

Del Favero R (1992). Un'esperienza di studio di tipologia forestale. Annali dell'Accademia Italiana di Scienze Forestali 41: 65-84

Del Favero R (2000). Biodiversità e indicatori nei tipi forestali del Veneto. CD included. Commissione Europea, Accademia Italiana di Scienze Forestali, Direzione Regionale delle Foreste e dell'Economia Montana, Regione Veneto, Mestre, VE.

Du Bus De Warnaffe G, Devillez F (2002). Quantifier la valeur écologique des milieux pour intégrer la conservation de la nature dans l'aménagement des forêts: une démarche multicritères. Annales of Forest Science 59: 369-387.

English Nature (2001). European significance of British woodland types. English Nature Report
Number 460. English Nature, Peterborough. English Nature (2003). Lowland heathland SSSIs: Guidance on conservation objectives setting and condition monitoring. Report Number 511. English Nature, Peterborough

European Commission/DG Environment (2000). Managing Natura 2000 sites: the provisions of Article 6 of the "Habitats" Directive 92/43/EEC.

European Commission/DG Environment (2003a). Interpretation Manual of European Union Habitat. EUR 25

European Commission/DG Environment (2003b). Natura 2000 and forests "challenges and opportunities". Interpretation guide.

European Commission (2005). Note to the Habitat Committee. Assessment, monitoring and reporting of conservation status - Preparing the 20012007 report under Article 17 of the Habitats Directive (DocHab-04-03/03 rev.3)

EEA (2003). EEA core set of indicators. Revised version April 2003. Technical report.

FAO (2003). International Conference on the Contribution of Criteria and Indicators for Sustainable Forest Management: the Way Forward (CICI-2003). Report. Guatemala City, 3-7 February 2003. FAO, Rome.

Ferris R, Humphrey JW (1999). A review of potential biodiversity indicators for application in British forests. Forestry 72 (4): 313-328.

Gasparini P, Tosi V (2000). Foreste e biodiversità: principi e metodi di monitoraggio. Monti e Boschi 6: 5-21.

Goriup P (1999). The New Forest Woodlands. Pisces, Newbury.

Hall JB (1991). Multiple-nearest-tree sampling in an ecological survey of Afromontane catchment forest. Forest Ecology and Management 42: 245266.

JNCC (2004). Common Standards Monitoring Guidance for Woodland Habitats. Version February 2004. JNCC, Peterborough.

JNCC (2006). Natura 2000 Standard Data Form. [online] URL: http:/www.jncc.gov.uk/ProtectedSites/SACselection/n2kforms/UK0012557.pdf

Kapos V, Jenkins MD, Lysenko I, Ravilious C, Bystriakova N, Newton A (2001). Forest biodiversity indicators. Tools for policy-making and management. UNEP-WCMC, Cambridge.

Keddy PA, Drummond CC (1996). Ecological properties for the evaluation, management, and restoration of temperate deciduous forest ecosystems. Ecological Applications 6 (3): 748-762.

Lähde E, Laiho O, Saksa T (1999). Stand structure as the basis of diversity index. Forest Ecology and Management 115: 213-220.

Larsson TB (2001). Biodiversity evaluation tools for European forests. Ecological Bulletins 50 . Wallin \& Dalholm Press, Lund, Sweden.

Lamonaca A (2005). Rete Natura 2000. Analisi dell'assetto forestale di un SIC. Sherwood 115: 23-29.
Lasen C (2000). Piano ambientale per le riserve di Pian di Landro Baldassarre e Piaie Longhe - Millifret. Veneto Agricoltura, unpublished work. Lazzarini A (1997). Un progetto fallito. Il bosco del Cansiglio dopo la riforma veneziana del 1792. Ricerche di storia sociale e religiosa, XXVI. [online] URL: http:/www.cansiglio.it/biblioteca/lazzarini/progettofallito.pdf

Lindenmayer DB, Margules CR, Botkin DB (2000). Indicators of Biodiversity for Ecologically Sustainable Forest Management. Conservation Biology 14 (4): 941-950.

Ministero Ambiente (2003). Manuale per la gestione dei siti Natura 2000: lo strumento tecnico per l'applicazione delle Linee Guida. 25 November 2003. [online] URL: http:/www2.minambiente.it/scn/gestionesiti/index.php?sez=3\&cap=3

MCPFE (2003). Improved Pan-European Indicators for Sustainable Forest Management as adopted by the MCPFE Expert Level Meeting 7-8 October 2002. Wien, Austria.

Morisita M (1954). Estimation of population density by spacing method. Memoirs of the Faculty of Science Kyushu University, Series E 1: 187-197. Noss RF (1990). Indicators for monitoring biodiversity: a hierarchical approach. Conservation Biology 4: 128-133.

Noss RF (1999). Assessing and monitoring forest biodiversity: A suggested framework and indicators. Forest Ecology and Management 115: 135146.

OECD (1994). Environmental indicators: OECD Core Set. Paris

Roberts-Pichette P, Gillespie L (1999). Terrestrial vegetation monitoring protocols. Eman Occasional Paper Series, Report 9. Canada Centre for Inland Waters, Burlington, Ontario, Canada.

Prabhu R, Colfer CJP, Venkateswarlu P, Tan LC, Soekmadi, R, Wollenberg E (1996). Testing criteria and indicators for the sustainable management of forests: phase 1. Final report CIFOR. Jakarta, Indonesia.

Schmidt di Friedberg P (1987). Gli indicatori ambientali. Valori, metri, e strumenti nello studio di impatto ambiemtale. Franco Angeli, Milano.

Shaw P, Wind P (1997). Monitoring the condition and biodiversity status of European Conservation Sites. A discussion paper. Final Draft. Report to the EEA on the behalf of the ETC/NC, Paris.

Sheil D, Ducey MJ, Sidiyasa K, Samsoedin I (2003). A new type pf sample unit for the efficient assessment of diverse tree communities in complex forest landscapes. Journal of Tropical Forest Science 15: 117-135.

Tubbs CR (1986). The New Forest: A Natural History. Collins, London.

Wätzold F, Schwerdtner K (2005). Why be wasteful when preserving a valuable resource? A review article on the cost-effectiveness of European biodiversity conservation policy. Biological Conservation 123: 327-338. 